Katarzyna Jaworska-Biskup

Uniwersytet Szcrecinski

\title{
DYSLEKSJA ROZWOJOWA W KONTEKŚCIE EDUKACJI OBCOJĘZYCZNEJ - PERSPEKTYWA INTERDYSCYPLINARNA
}

\section{Developmental dyslexia and foreign language teaching: An interdisciplinary perspective}

\begin{abstract}
Many branches of science and academic disciplines such as psychology, linguistics or medicine fuel interest in developmental dyslexia by proposing a variety of theories attempting to determine what causes dyslexia and how dyslexia influences the acquisition of a foreign. For this particular reason, a foreign language teacher must not only be equipped with a sound methodological knowledge but also familiar with current approaches to dyslexia. The main tenet of this article is that dyslexia-related difficulties have a tremendous impact on second language learning, which necessitates the inclusion of specially adapted techniques and instruction.
\end{abstract}

\section{Wstęp}

Mimo wielu badań dotyczących zarówno pochodzenia, jak i mechanizmów zaburzeń czytania i pisania, szeregu publikacji na świecie i ostatnio także w Polsce na temat terapii specjalnych potrzeb edukacyjnych, oraz licznych kampanii na rzecz pogłębiania świadomości tego problemu wśród zarówno nauczycieli, jak i rodziców, zagadnienie dysleksji rozwojowej jest nadal chętnie poddawane pod dyskusję. Choć termin dysleksja rozwojowa jest znany, potrzeby ucznia dyslektycznego nie zawsze są respektowane w szkole (Jaworska-Biskup 2010). Współczesne teorie dysleksji rozwojowej wyraźnie podkreślaja, że wbrew powszechnym jeszcze opiniom dysleksja to nie tylko zaburzenie czytania i pisania, ale zbiór deficytów na poziomie poznawczym widocznych na różnych polach, takich jak język i związana z nim komunikacja. Dysleksja powinna być 
postrzegana interdyscyplinarnie i globalnie. Interdyscyplinarność dotyczy współpracy specjalistów z różnych dziedzin naukowych, takich jak psychologia, medycyna, językoznawstwo, metodyka itp. Globalne ujęcie problemu dysleksji wywodzi się z koncepcji Uty Frith (1999), która wyróżniła kilka poziomów dysleksji, a mianowicie: poziom biologiczny związany z uwarunkowaniami genetycznymi (wrodzonymi), poziom poznawczy (funkcje językowe), oraz poziom behawioralny (zaburzenia komunikacji i problemy emocjonalnospołeczne). Trudności ucznia dyslektycznego są także zależne od środowiska domowego i edukacyjnego czy kulturowego, a także od wielu innych indywidualnych cech jednostki. Podobnie do dysleksji podchodzi Gavin Reid (2007), który wymienia trzy główne czynniki determinujące każdy przypadek dysleksji: czynniki neurobiologiczne, czynniki poznawcze oraz czynniki edukacyjne i środowiskowe. Idąc tym tropem można nakreślić ogólny profil osoby dyslektycznej, na który składa się odmienne od pozostałej populacji przetwarzanie informacji, spowodowane odmiennym rozwojem struktur mózgowych i połączeń neuronalnych odpowiedzialnych za przetwarzanie takich informacji, co prowadzi w konsekwencji do wykształcenia indywidualnego stylu uczenia się (Reid 2007). To, czy środowisko zarówno szkolne, jak i domowe stworzy przyjazny klimat dla stylu poznawczego osoby dyslektycznej, rzutuje na sukces albo porażkę edukacyjna. Niestety metody przekazywania i egzekwowania wiedzy, preferujące styl myślenia lewo półkulowy, oparty na rozumowaniu logicznym i indukcyjno-dedukcyjnym, nie idą $w$ parze $z$ potrzebami poznawczymi osoby dyslektycznej, która wymaga strategii angażujących prawą półkulę mózgu, a więc uczenia się wzrokowo i globalnie itp.

\section{Dysleksja - perspektywa psychologa}

Badania nad dysleksją na gruncie psychologii dotyczą między innymi: definicji dysleksji i jej etiologii, współwystępowania dysleksji z innymi zaburzeniami, diagnozy i metod terapii, funkcjonowania osób z dysleksją w sferze poznawczej i społecznej (Krasowicz-Kupis 2006, 2008). Najwięcej kontrowersji budzi sama definicja dysleksji. Najczęściej cytowaną definicją jest definicja Światowego Towarzystwa Dysleksji, według której dysleksja to:

Jeden z. wielu różnych rodzajów trudności w uczeniu się. Jest specyficznym zaburzeniem o podto:் jezykowym uwarunkowanym konstytucjonalnie. Charakteryzuje sie trudnościami w dekodowaniu pojedynczych stów, co najcześciej odzwierciedla niemystarczajace zdolności przetwarzania fonologicznego. Trudności w dekodowaniu pojedynczych stów sq zazwyczaj niewspótmierne do wieku oraz zdolności poznawczych i umiejetności szkolnych; trudności te nie sq uynikiem ogólnego zaburzenia rozџwoju ani zaburzeń sensorycznych. Dysleksja manifestuje sie różnymi trudnościami w odniesieniu do różnych form komunikacji jezylkowej. Czesto oprócz. trudności w caytaniu dodatkowo pojawiaja sie trudności w opanowaniu sprawności w zakeresie çynności pisania i poprawnej pisowni (Krasowicz-Kupis 2008: 53). 
Dysleksja nie jest wynikiem ani braku motywacji ani niskiego poziomu inteligencji, lecz jest zależna od zaburzeń na poziomie przetwarzania informacji w mózgu. Szczególną rolę odgrywa przetwarzanie informacji fonologicznych związanych z rozumieniem relacji litera i głoska (Goulandris 2003; Downey i in. 2000; Stanovich 1988). Kompetencja (sprawność) fonologiczna umożliwia sprawne różnicowanie głosek i dokonywanie operacji na czastkach fonologicznych takich jak sylaby, logotomy i głoski (Petrus i Bogdanowicz 2004). Na przetwarzanie fonologiczne składają się trzy istotne elementy: świadomość fonologiczna (phonological awareness), szybkie nazywanie (phonological recoding in lexical access-rapid naming) i werbalna pamięć operacyjna (working memory) (Bogdanowicz 2004). Trudności przetwarzania fonologicznego występują pod postacią: trudności w analizie głoskowej, zapamiętywaniu i powtarzaniu sztucznych słów, wolnego tempa nazywania, mówienia czy trudności w manipulowaniu fonemami (Krasowicz-Kupis za Bogdanowicz 2004). Przetwarzanie fonologiczne odgrywa zasadniczą rolę w nauce czytania i pisania, ponieważ dotyczy umiejętności syntezy głoskowej (kojarzenia liter z głoskami i łączeniem ich w słowa) oraz analizy głoskowej (podziału wypowiadanych słów na głoski i przypisywanie im odpowiednich liter). Zrozumienie powiązań, jakie zachodzą na etapie tych dwóch procesów, umożliwia sprawne czytanie i pisanie, oraz dekodowanie nowych nieznanych dotąd słów lub pseudo-słów (Hatcher i Snowling 2008). Wątek świadomości fonologicznej rozwinęła Margaret Snowling (2000) w swojej koncepcji dysleksji jako zaburzenia uwarunkowanego deficytem fonologicznym:

\section{[...] dysleksja jest specyficzna forma ostabienia funk.ji jezykowych, bedaca skutkiem sposobu w jaki mórg dokonuje enkodowania cech fonologicznych wypowiadanych stów. Jadro deficytu tkwi w przetwarzaniu fonologicznym $i$ ma swoje źródto $w$ stabo zróżnicowanych reprezentacjach fonologicznych. Dysleksja szczególnie wplywa na czytanie i pisanie, ale jej skutki moga takize w toku rozwoju wplywać modyfikujaco na różnorodne przejawy w obrebie zachowania (Snowling 2000: 213 za Krasowicz-Kupis 2008).}

Warto zanotować definicje dysleksji proponowane przez największe polskie autorytety w tej dziedzinie: definicje Krasowicz-Kupis (2008 etc.) i Bogdanowicz (2004). Krasowicz-Kupis (2008) definiuje dysleksję jako zaburzenie różnych form komunikacji, Bogdanowicz (2004) jako skutek deficytów integracji percepcyjno-motorycznej, innymi słowy deficytów w zakresie integracji różnych analizatorów: wzrokowych, słuchowych, dotykowych i kinestetycznych. Najnowsze definicje (Szczerbiński 2007) mają charakter bardziej opisowy i próbuja odpowiedzieć na pytanie, czym dysleksja jest, a czym nie jest. Istnieje cała gama paradoksów dysleksji, które zamazują obraz tego zjawiska i czynią z niego deficyt indywidualny i osobniczy. Do takich paradoksów zalicza się: współwystępowanie wielu deficytów jednocześnie (dysleksji często towarzyszy ADHD), różna skala objawów dysleksji i stopień ich występowania u różnych osób, różna etiologia dysleksji lub polietiologia, niejednorodność zjawiska 
(dysgrafia, dysortografia, dysleksja), fluktuacja objawów w zależności od stanu emocjonalnego, ekspozycji na język itp. Przy diagnozie dysleksji należy także wykluczyć takie czynniki, jak zaniedbanie edukacyjne czy środowiskowe, złe funkcjonowanie narządów zmysłów (niedosłuch czy wady wzroku) oraz schorzenia neurologiczne (Bogdanowicz 2004). Niewatpliwie duże znaczenie ma wczesne rozpoznanie dysleksji, już w okresie przedszkolnym, czemu służy skala ryzyka dysleksji opracowana przez Martę Bogdanowicz. Po trafnej diagnozie dziecko powinno być poddane terapii uwzględniającej odpowiednie metody pracy. Przykładem takiego podejścia jest Metoda Dobrego Startu Marty Bogdanowicz wykorzystująca polisensoryczne uczenie się. Z tą metodą powinni zapoznać się także nauczyciele języków obcych, gdyż wiele jej elementów można bezpośrednio zaadaptować do nauki języka obcego. Współczesne badania nad zagadnieniem dysleksji dotyczą jej etiologii. Wśród koncepcji wyjaśniających pochodzenie dysleksji wyróżnia się teorię genetyczna, teorię neuroanatomiczną i neurofunkcjonalna, teorię deficytu wielkokomórkowego, teorię deficytu móżdżkowego i teorię hormonalną (Krasowicz-Kupis 2008). Wszystkie wymieniają czynniki biologiczne i neurorozwojowe jako główne przyczyny dysleksji. Dysleksja kształtuje się na dwóch poziomach (za Bogdanowicz 2005): poziomie przyczyn pierwotnych (oddziaływanie czynników patogennych na centralny układ nerwowy powodujące jego mikrozmiany; są to uwarunkowania genetyczne, organiczne, opóźnione dojrzewanie funkcji centralnego układu nerwowego) i poziomie przyczyn bezpośrednich (fizjologiczne zaburzenia czynności układu nerwowego mające postać dysfunkcji czynności poznawczych i motorycznych bioracych udział w czytaniu i pisaniu oraz ich współdziałanie). U podłoża dysleksji leżą zaburzenia procesów orientacyjno-poznawczych, ruchowych i ich integracji, które dotyczą uwagi i pamięci, pamięci sekwencyjnej i płynności słowa, percepcji, motoryki i lateralizacji czynności ruchowych oraz integracji percepcyjno-motorycznej tych funkcji (Bogdanowicz i Adryjanek 2005).

\section{Dysleksja-perspektywa językoznawcy}

Komparastyka funkcjonowania osób cierpiących na zaburzenia dysleksji w różnych językach pokazuje, że trudności w nauce zależą od samego języka, a dokładniej od jego poziomu transparentności zwanego także głębią ortograficzną (orthographic depth) (Liberman i in. 1980; Katz i Feldman 1981; Frost i in. 2007). Zjawisko głębi ortograficznej ilustruje się liniowo: poszczególne języki w zależności od ich poziomu transparentności klasyfikuje się jako transparentne (włoski, hiszpański, grecki, turecki, niemiecki) lub mało transparentne (angielski, francuski) (Frost i in. 2007). Transparentność (spelling-to-phonology-consistency) dotyczy każdego poziomu fonologicznego, na przykład rymów czy sylab. Im język jest bardziej transparentny, tym łatwiejszy do nauczenia. Stwierdzenie to popieraja liczne badania, na przykład Wimmer i in. (1999) nad funkcjonowaniem 
językowym niemieckich $\mathrm{i}$ angielskich osób z dysleksją, które pokazują lepsze wyniki uzyskane w teście czytania długich słów i pseudo-słów w grupie niemieckich dyslektyków. Według innych badań (Glushko 1979) odtworzenie słów o małej transparentności zajmuje więcej czasu, gdyż poprawna wymowa słów opiera się w dużej mierze na zjawisku podobieństwa lub analogii. Człowiek zapamiętuje wymowę wyrazów poprzez analogię, szukając wzajemnych par mających te same cechy fonologiczne. W językach mało transparentnych reguła ta nie zawsze się sprawdza, a większość wyrazów i ich wymowa/pisownia musi zostać przyswojona pamięciowo. Język angielski jest systemem bardzo nieregularnym, charakteryzującym się wysoką polisemicznościa (wieloznacznością) słów, znaczną liczbą homografów i homofonów oraz widoczną dla każdego uczącego się tego języka rozbieżnością między zapisem a wymową. Osoba, która podejmuje próbę uczenia się języka angielskiego jako obcego, musi posiadać dobrą pamięć, zwłaszcza pamięć fonologiczną, która umożliwia trwałe przyswojenie relacji grafem/fonem. Porównując język polski z językiem angielskim można zauważyć, że język polski jest językiem stosunkowo regularnym pod względem pisowni, mniej pod względem czytania. Język angielski jest językiem nieregularnym na wszystkich tych płaszczyznach. Badania potwierdzaja (za Petrus i Bogdanowicz 2004), że specyfika języka wpływa na rozwój kompetencji fonologicznej. Cechy danego języka mogą mieć znaczenie w procesie przyspieszania lub opóźniania kształtowania sprawności fonologicznej. Przyczyną takiego zjawiska są różnice między językiem angielskim i polskim. Język angielski to język o dużej ilości wyrazów rymujących się ze sobą z dominacją krótkich, jednosylabowych rzeczowników i rymów męskich. Język polski obfituje w rymy żeńskie i grupy spółgłoskowe. Zatem w języku polskim w porównaniu z językiem angielskim istnieje mniejsza liczba rymów i aliteracji. Różnice te decyduja o sposobie nauki czytania przez dzieci; dzieci polskie ucza się czytać wykorzystując strategię głoskowania, która nie ma zastosowania w języku angielskim z uwagi na wysoką nietransparentność (Szczerbiński 2001 za Petrus i Bogdanowicz 2004). Co więcej, Petrus i Bogdanowicz (2004) zakładaja, że nauka języka drugiego (obcego) może mieć kompensacyjny wpływ na budowanie sprawności fonologicznych w języku ojczystym. Autorki czerpia wnioski z teorii Lundberga (2003), dotyczacej transferu kompetencji fonologicznej, zgodnie z którą sprawność dobrze rozwinięta w języku ojczystym przechodzi na kolejne języki. Zatem nauka języka obcego ma charakter terapeutyczny. Badanie Petrus i Bogdanowicz (2004) nad dziećmi w wieku przedszkolnym uczącymi się i nieuczącymi się języka angielskiego wykazują, że intensywny trening w jezzyku angielskim, polegający na grach i zabawach językowych typu rymowanki, piosenki, wierszyki itp. wpływa na rozwój wrażliwości na rymy zarówno w języku polskim, jak i angielskim; im większa była intensywność nauki, tym związek pomiędzy wynikami w obu językach był silniejszy. Oczywiście wyniki takich badań zachęcają do nauki języka obcego, 
Katarzyna Jaworska-Biskup

lecz z drugiej strony należy pamiętać o odpowiednich metodach. Złe techniki nauczania mogą wywołać efekt odwrotny. 


\section{Dysleksja-perspektywa ucznia}

Nauka każdego języka wymaga dobrze rozwiniętej sprawności fonologicznej, pamięci operacyjnej i krótkotrwałej, szybkości przetwarzania informacji, automatyzacji itp. Uważa się, że skoro dysleksja jest zaburzeniem ogólnojęzykowym, jej objawy będą dotyczyły nie tylko języka ojczystego, ale każdego kolejnego języka. Według tej teorii, propagatorem której są Sparks i Ganschow $(1989,1998)$, problemy natury językowej są wywołane deficytami kodowania w obszarze semantycznym, syntaktycznym i fonologicznym. Esther Geva (2000) wprowadziła termin międzyjęzykowego przenoszenia, które oznacza przenoszenie umiejętności fonologicznych z języka pierwszego na poprawność czytania wyrazów w języku drugim. Istnieje także stały związek pomiędzy typem języka ojczystego a kompetencją w języku drugim (dodatkowym) u dzieci dwujęzycznych (Siegel i Smythe 2004). Obok cech dystynktywnych samego języka należy także wziąć pod lupę sposoby nauczania języka. Obecna metodyka nauczania języków obcych zdominowana jest przez metodę komunikacyjną, w której często zaniedbuje się tłumaczenie reguł językowych na rzecz dochodzenia do znaczenia $z$ kontekstu. Według takiego podejścia sama ekspozycja na jezzyk wystarcza, aby zapewnić jego przyswojenie. Podejście takie dyskryminuje uczniów mniej zdolnych językowo oraz uczniów z problemem dysleksji rozwojowej. Uczeń dyslektyczny zmuszony do obcowania z językiem w klasie, gdzie dominuja takie metody, funkcjonuje $\mathrm{w}$ świecie niejasnych mu reguł $\mathrm{i}$ niezrozumiałych słów. Można zatem mówić o dwóch rodzajach podejścia do nauczania języka obcego: podejściu holistycznym (słowa są wprowadzane w danym kontekście komunikacyjnym; uczeń sam dochodzi do znaczenia wyrazu) i o podejściu analitycznym (wyrazy podlegają analizie fonologicznej i semantycznej). Edukacja ucznia dyslektycznego powinna wykorzystywać metodę analityczną.

Skoro istnieje stała relacja pomiędzy kompetencją w języku ojczystym i języku obcym, zakres i rodzaj błędów będzie podobny, lub w zależności od specyfiki języka obcego większy. Typowe dla dysleksji błędy, jak omijanie, przestawianie, dodawanie liter $\mathrm{w}$ wyrazie, błędy w pisowni i wymowie, słaba pamięć będą widoczne na lekcji języka obcego. Trudności ucznia dyslektycznego na lekcji języka obcego będą dotyczyły: trudności w zrozumieniu relacji głoska/litera, reguł morfologicznych (budowy wyrazów) i gramatycznych, zapamiętywaniu i przywoływaniu wyrazów z pamięci, szybkim nazywaniu (Ganschow i in. 2000; Crombie 1997b; Goswami 1997). Dysleksja to przede wszystkim zaburzenia natury przetwarzania fonologicznego, innymi słowy zdolność odróżniania dźwięków mowy ludzkiej. W języku obcym objawia się to trudnościami w opanowaniu graficznej i dźwiękowej reprezentacji danego wyrazu oraz licznymi błędami w pisowni (przestawianie liter, opuszczanie liter itp.). Zaburzenia przetwarzania fonologicznego prowadzą do trudności w pisaniu i czytaniu, czyli dekodowaniu i enkodowaniu wyrazów. Deficyty pamięci 
charakteryzują się zaburzeniami pamięci fonologicznej i sekwencyjnej. Zaburzenia pamięci fonologicznej (phonological memory) polegają zwykle na trudnościach w zapamiętywaniu i odróżnianiu głosek w wyrazie, trudnościach w zapamiętywaniu słów o podobnej wymowie np. floor - podłoga, flour - mąka, flower - kwiatek, dessert - deser, desert - pustynia, myleniu wyrazów, gubieniu liter $\mathrm{w}$ wyrazie, przestawianiu liter $\mathrm{w}$ wyrazie, dodawaniu zbędnych liter, nieprawidłowej wymowie. Dysleksja to także zaburzenia pamięci sekwencyjnej (sequential memory), czyli zapamiętywanie danych uszeregowanych $w$ ciagi $i$ sekwencje. $\mathrm{Na}$ lekcji języka obcego uczeń musi opanować wiele ściśle uporząadkowanych informacji najczęściej w postaci tabel np. czasowników nieregularnych, idiomów, zaimków, form odczasownikowych, struktur gramatycznych (strona bierna, mowa zależna), przyimków itp.

Kolejna grupa trudności dysleksji to trudności przetwarzania, magazynowania i odtwarzania informacji (zwłaszcza informacji semantycznych, morfologicznych, syntaktycznych). Trudności tego typu rzutują na zaburzenia zapamiętywania wyrazów obcych, reguł językowych itp.

Deficyty przedstawione powyżej, przede wszystkim słaba reprezentacja fonologiczna obcych wyrazów prowadzą do trudności w czytaniu i pisaniu w języku obcym. Dodatkową barierą jest brak odniesienia do informacji (podpowiedzi) semantycznych i syntaktycznych. Osoba dyslektyczna czytająca tekst w języku obcym nie może budować rozumienia tego tekstu w oparciu o słowa-klucze, gdyż nie ma wystarczających umiejętności językowych, a nowe słowa są często puste znaczeniowo.

\section{Dysleksja - perspektywa nauczyciela}

Z perspektywy edukacji obcojęzycznej dysleksja jest deficytem kodowania i przetwarzania informacji językowych, co powinno skutkować wolniejszym tempem podawania informacji oraz indywidualnym sposobem wprowadzania informacji (Schneider i Crombie 2003; Reid 2007). Przy wyborze odpowiedniej strategii nauczania osób z dysleksją należy uwzględnić kilka elementów (Reid 2007): kontekst (liczebność klasy, wyposażenie sal, wiek ucznia, wsparcie lub jego brak ze strony rodzica, pedagoga itp.), ewaluacja (ocena trudności i mocnych stron ucznia - pomocny może okazać się wywiad z rodzicem, uczniem, analiza opinii dostarczonej przez poradnię), program nauczania (określenie wymagań nauczyciela wobec uczniów, ustalenie kryteriów oceny itp.), sylwetka ucznia (co motywuje danego ucznia do pracy, jaki styl poznawczy uczeń preferuje). Podejście ukierunkowane na ucznia z dysleksją musi mieć cechy takie, jak: multisensoryczność (polisensoryczność, wielozmysłowość, wielokanałowość), sekwencyjność i cykliczność (reguła małych kroków wprowadzanie materiału stopniowo w małych porcjach), przeuczenie i intensywność (powtórka materiału), indywidualizm (uwzględnienie indywidualnego profilu ucznia), bezpośredniość (tłumaczenie reguł, a nie ich 
przewidywanie z kontekstu), interaktywność (wykorzystanie technik informacyjno-komunikacyjnych). W pracy z uczniem dyslektycznym należy także stosować gry i zabawy językowe typu bingo, scrable, memory, hangman, guess who itp., które w sposób naturalny pomagają w konsolidacji danego materiału Tak szerokie spektrum adaptacji programu nauczania może budzić wątpliwości co do celowości wdrażania dziecka dyslektycznego do szkoły masowej. Jak jednak podkreślają specjaliści zajmujący się zagadnieniem dysleksji, uczeń dyslektyczny odniesie sukces w szkole masowej, jeśli uwzględniona zostanie pomoc pedagogiczna w formie zindywidualizowanego programu nauczania, zindywidualizowanego systemu oceniania, metod nauczania dostosowanych do ucznia oraz specjalnych rozwiązań organizacyjnych, co niewątpliwie powinno leżeć w kompetencji władz oświatowych (Bogdanowicz i Adryjanek 2005; DiFino $i$ in. 2008).

Pierwsze badania prowadzone przez Sparks i Ganschow (1989, 1998c) w języku hiszpańskim pokazały, że edukacja obcojęzyczna ucznia z dysleksja rozwojową wymaga zastosowania metody wielozmysłowej, zwanej także VAKT od ang. Visual, Auditory, Kineasthetic and Tactile. Jak stwierdzili i udowodnili Sparks $\mathrm{i}$ in. (1998c), kontakt $\mathrm{z}$ językiem pisanym i czytanym na drodze wielozmysłowej usprawnia funkcjonowanie podstawowych umiejętności językowych. Nawet prosta czynność, jak układanie klocków w kształcie liter i jednoczesne ich wymawianie angażuje kanał kinestetyczny, wzrokowy i słuchowy. Podobne badania prowadzili także Schneider i Crombie (2003), Bradley i Bryant (1983), Gilingham and Stillman (1960), Turner and Pughe (2003). W Polsce propagatorką badań z dziedziny dysleksji w kontekście języków obcych jest Joanna Nijakowska, która w licznych publikacjach (2004, 2008 etc.) potwierdza wyniki badań uzyskanych przez naukowców na świecie. Szczególny nacisk w tej metodzie kładzie się na kształcenie sprawności przetwarzania fonologicznego i relacji fonem/grafem. Metoda wielokanałowa została zastosowana w metodzie Orton-Gillingham, która składa się z takich aktywności, jak: dryle językowe przy pomocy kart (karty przedstawiające podział wyrazu na fonemy, sylaby itp. mają za zadanie wzmocnienie pamięci wzrokowej sekwencji liter w danym wyrazie), listy wyrazów, ćwiczenia polegające na odczytywaniu wyrazów, łączeniu fonemów, odwzorowywanie kształtu liter w danym wyrazie itp. Na początku zajęć uczeń zaznajamiany jest jedynie z dwoma samogłoskami angielskimi (a, i) oraz ośmioma spółgłoskami (f, l, b, j, h, m, p, t). Każda z liter wprowadzana jest wraz z wyrazem ją ilustrującym. Po opanowaniu przez ucznia podstawowych liter $z$ ich graficzną i dźwiękową reprezentacja uczeń dokonuje łączenia liter w sekwencje typu vc (samogłoska/spółgłoska), cv (spółgłoska/samogłoska), a w miarę postępów cvc, ccvc, ccv cc (Reid 2007). Na lekcji języka obcego metoda wielozmysłowa może być wykorzystana na wiele sposobów, np.

- zmysł wzroku (wykresy, tabelki, obrazki, wizualizacje, mapy myśli, karty obrazkowe, prezentacje Power Point, słownik obrazkowy), 
- zmysł słuchu (nagrywanie słownictwa do wielokrotnego odtwarzania w domu, powtarzanie słownictwa za nauczycielem, książka mówiona),

- zmysł dotyku (wodzenie palcem po kształcie liter w powietrzu, na podłożu, na specjalnej macie, układanie klocków w kształcie liter, liter wyciętych z kartonu, odwzorowywanie kształtu liter wykropkowanych na papierze),

- integracja zmysłów (układanie słów z klocków przy jednoczesnym odczytywaniu poszczególnej litery, wodzenie palcem po kształcie liter i wymawianie liter na głos).

Szczególnie pomocne są także programy komputerowe, które oferują wielozmysłowy trening wszystkich sprawności językowych poprzez odwołanie się do obrazu, dźwięku i zapisu.

Obok metod multisensorycznych propaguje się terapię w zakresie fonologii języka, a więc ćwiczenia relacji głoska i litera w języku obcym (Connelli 1993; Hoien i Lundberg 1988; Lundberg i in. 1988; Stuart i Coltheart 1988; Bentin i in. 1991; Alegria 1982). Według Hatcher i Snowling (2008) nauka języka powinna być trzy-stopniowa: dziecko musi nabyć wiedzę dotyczącą liter (kształt, użycie), przyswoić wiedzę z zakresu głosek (wymowa), a następnie swobodnie stosować tę wiedzę w nauce nowych słów, czytaniu, pisaniu itp. Lundberg i in. (1980) w badaniu nad dziećmi szwedzkimi pokazują, że trening umiejętności fonologicznych we wczesnym dzieciństwie przyczynia się do zwiększenia wiedzy o fonologicznej stronie danego języka. Osoby, które uczestniczyły w eksperymencie, robiły mniej błędów w czytaniu i pisaniu. Do podobnych wniosków dochodzą Bradley i Bryant (1983) w odniesieniu do języka angielskiego. Trening świadomości fonologicznej przynosi najlepsze efekty, jeśli towarzyszy mu meta-kognitywne tłumaczenie zasad języka, co potwierdza badanie Hatcher (1994) nad dziećmi z dysleksją w wieku 7 Lat. Te dzieci, które otrzymały trening świadomości fonologicznej i jednocześnie były uczone dochodzenia do reguł, uzyskały najlepsze wyniki. Instrukcja bezpośrednia, czyli tłumaczenie reguł gramatycznych, leksykalnych i fonetycznych zwiększa tempo i poprawność uczenia się.

Popularną metodą uczenia skomplikowanego systemu 44 fonemów angielskich jest metoda syntetyczna (synthetic phonics), która z założenia opiera się na wprowadzaniu pojedynczych fonemów, a następnie łączeniu ich w proste zrosty. Na przykład, wyraz dog (pies) można podzielić na trzy główne fonemy. Uczeń poznaje dźwiękowy ekwiwalent każdej litery, a następnie łączy (scala) je i odczytuje cały wyraz. Metoda ta jest często wymieniana wraz z metoda analityczną (analitical phonics), w której uczeń analizuje fonemy i grafemy w wyrazach szukając podobieństwa (Lewis i Ellis 2009).

Do innych technik pomocniczych można zaliczyć: metodę nauczania wzajemnego (reciprocal teaching), program wspólnego czytania strategicznego (collaborative strategic reading), strategie uczenia się wspierane przez rówieśników (peer assisted learning strategies), tutoring rówieśniczy, czytanie w parach, 
myślenie w parach (za Topping 2008). Praca z uczniem dyslektycznym jest wielokierunkowa i powinna być podejmowana przez osobę znająca zagadnienie z wielu perspektyw, co wymaga zapoznania się z bogatą literaturą i nabycia praktyki. Z uwagi jednak na rosnącą liczbę przypadków dysleksji każdy nauczyciel powinien posiadać wiedzę umożliwiającą mu dostosowanie lekcji do potrzeb ucznia dyslektycznego w klasie. Przedstawiona poniżej tabelka jest próbą ilustracji wpływu dysleksji na nauczanie języka angielskiego. Metody terapii są jedynie przykładowe.

\begin{tabular}{|c|c|c|}
\hline $\begin{array}{l}\text { SYMPTOMY } \\
\text { DYSLEKSJI }\end{array}$ & $\begin{array}{c}\text { OBJAWY } \\
\text { W JEZZYKU OBCYM }\end{array}$ & $\begin{array}{l}\text { METODY } \\
\text { TERAPII }\end{array}$ \\
\hline $\begin{array}{l}\text { Zaburzenia pamięci } \\
\text { fonologicznej i } \\
\text { sekwencyjnej } \\
\text { (trudności w } \\
\text { zapamiętywaniu) }\end{array}$ & $\begin{array}{l}\text { Trudności w zapamiętywaniu } \\
\text { kolejności liter w wyrazie, } \\
\text { opuszczanie, przestawianie liter np. } \\
\text { sudenly zamiast suddenly, moter zamiast } \\
\text { mother, tet zamiast tent, mylenie liter, } \\
\text { przekręcanie liter, dodawanie, } \\
\text { opuszczanie, przestawianie liter, } \\
\text { sylab, trudności w opanowaniu } \\
\text { słownictwa np. dni tygodnia, pór } \\
\text { roku, nazw miesięcy, rzeczowników } \\
\text { abstrakcyjnych, wyrazów trudnych } \\
\text { pod względem pisowni, wymowy, } \\
\text { idiomów, przysłów itp., trudności w } \\
\text { korzystaniu ze słownika i } \\
\text { zapamiętywaniu definicji wyrazu, } \\
\text { trudności w opanowaniu reguł } \\
\text { jezykowych, gramatycznych i } \\
\text { wyjątków od tych reguł. } \\
\text { Trudności w zapamiętywaniu } \\
\text { poleceń w danym ćwiczeniu, teście, } \\
\text { poleceń odczytywanych przez } \\
\text { nauczyciela, nagranych na taśmę. } \\
\text { Trudności w zapamiętywaniu pracy } \\
\text { domowej. }\end{array}$ & $\begin{array}{l}\text { Techniki ułatwiające zapamiętywanie, } \\
\text { np. mnemotechniki, skojarzenia } \\
\text { słowne, wprowadzanie słownictwa } \\
\text { wielokontekstowo i wielozmysłowo, } \\
\text { wprowadzanie małej partii materiału } \\
\text { za pomoca listy wyrazów, } \\
\text { wprowadzanie słownictwa za pomoca } \\
\text { kart obrazkowych wraz z zapisem } \\
\text { fonetycznym, prezentacji Power Point } \\
\text { z obrazkowym i dźwiękowym } \\
\text { ekwiwalentem, wprowadzanie } \\
\text { słownictwa na kolorowym tle, } \\
\text { wprowadzanie rodziny wyrazów } \\
\text { podobnych do siebie znaczeniowo } \\
\text { lub morfologicznie, stosowanie tablicy } \\
\text { interaktywnej, wielokrotna powtórka, } \\
\text { nagrywanie słów na dyktafon do } \\
\text { odtwarzania w domu, odkrywanie } \\
\text { znaczenia wyrazów na drodze } \\
\text { metapoznawczej. } \\
\text { Częste komunikaty skierowane do } \\
\text { ucznia, monitorowanie indywidualnej } \\
\text { pracy ucznia, konsultacje } \\
\text { bezpośrednio po lekcji co do treści } \\
\text { materiału i pracy domowej. } \\
\text { Odpowiednia czcionka, duży druk } \\
\text { (Times New Roman, Comic Sans), } \\
\text { przejrzysta struktura materiału } \\
\text { prezentowanego w formie handout, } \\
\text { dobór odpowiedniego podręcznika } \\
\text { pod względem struktury i grafiki, } \\
\text { podziału materiału. }\end{array}$ \\
\hline $\begin{array}{l}\text { Zaburzenia } \\
\text { czytania (nauka } \\
\text { czytania) }\end{array}$ & $\begin{array}{l}\text { Niechęć do czytania w języku } \\
\text { obcym, błędy w czytaniu, brak } \\
\text { rozumienia tekstu, wolne tempo } \\
\text { czytania, przekręcanie słów np. saw i }\end{array}$ & $\begin{array}{l}\text { Ćwiczenia na bazie tekstu, dzielenie } \\
\text { tekstu na paragrafy, sekcje, } \\
\text { przewidywanie treści tekstu na } \\
\text { podstawie obrazków, nagłówków, }\end{array}$ \\
\hline
\end{tabular}




\begin{tabular}{|l|l|l|}
\hline was, ouri are. & $\begin{array}{l}\text { podkreślanie informacji w tekście, na } \\
\text { marginesie, rozmowa na temat tekstu, } \\
\text { streszczanie tekstu na forum klasy, } \\
\text { technika słów-kluczy w tekście, } \\
\text { techniki pomocnicze typu czytanie w } \\
\text { parach, myślenie w parach. }\end{array}$ \\
\hline
\end{tabular}

\begin{tabular}{|c|c|c|}
\hline $\begin{array}{l}\text { Zaburzenia pisania } \\
\text { (nauka pisania) }\end{array}$ & $\begin{array}{l}\text { Niechęć do pisania w języku obcym, } \\
\text { trudności w pisaniu wypracowań, } \\
\text { uczeń preferuje wypowiedzi ustne, } \\
\text { trudności w rozumieniu i stosowaniu } \\
\text { struktury wypowiedzi pisemnej w } \\
\text { języku obcym, trudności w } \\
\text { przepisywaniu z tablicy, pisaniu } \\
\text { testów, wolne tempo pisania, } \\
\text { niestaranny, nieczytelny charakter } \\
\text { pisma, nieprawidłowe trzymanie } \\
\text { długopisu, ołówka. }\end{array}$ & $\begin{array}{l}\text { Ocena dwustopniowa: za } \\
\text { poprawność i za kreatywność, } \\
\text { więcej czasu na przygotowanie } \\
\text { wypowiedzi pisemnej, technika } \\
\text { słów-kluczy, burzy mózgu. } \\
\text { Postrzeganie pisania jako } \\
\text { procesu, a nie produktu, } \\
\text { dyskusja na temat planu pracy, } \\
\text { wielokrotna korekta pracy. } \\
\text { Nie należy używać czerwonego } \\
\text { długopisu przy korekcie pracy } \\
\text { ucznia! Preferowany jest kolor } \\
\text { bardziej neutralny np. zielony. }\end{array}$ \\
\hline $\begin{array}{l}\text { Zaburzenia funkcji } \\
\text { słuchowo-językowych }\end{array}$ & $\begin{array}{l}\text { Trudności w wymowie obco } \\
\text { brzmiących słów, brak płynności w } \\
\text { wymowie, trudności w odróżnianiu } \\
\text { podobnie brzmiących wyrazów np. } \\
\text { bit - beat, live - leave, hit - heat. } \\
\text { Trudności w odczytywaniu } \\
\text { transkrypcji fonetycznej, pisownii } \\
\text { homofonów (wyrazów o takiej samej } \\
\text { wymowie, lecz innej pisowni i } \\
\text { znaczeniu) np. hear - here, see - sea, wear } \\
\text { - were, waist - waste, trudności w } \\
\text { odróżnianiu tzw. minimal pairs np. leaf } \\
\text { - leave, przekręcanie wyrazów } \\
\text { złożonych np. exercise-book, } \\
\text { unemployment, employee, homografów } \\
\text { (wyrazów o takiej samej pisowni, ale } \\
\text { innym znaczeniu) np. concert }\end{array}$ & $\begin{array}{l}\text { Intensywny trening } \\
\text { świadomości fonologicznej w } \\
\text { języku obcym, metoda } \\
\text { foniczna (analityczna i } \\
\text { syntetyczna). }\end{array}$ \\
\hline $\begin{array}{l}\text { Zaburzenia motoryki } \\
\text { dużej i małej }\end{array}$ & $\begin{array}{l}\text { Trudności w wykonywaniu ćwiczeń } \\
\text { angażujących ruch podczas zajęć, } \\
\text { powolność, ślamazarność. }\end{array}$ & $\begin{array}{l}\text { Więcej czasu na wykonanie } \\
\text { zadań, pomoc w wykonywaniu } \\
\text { zadań. }\end{array}$ \\
\hline $\begin{array}{l}\text { Trudności natury } \\
\text { psychofizycznej } \\
\text { (związane zarówno z } \\
\text { dolegliwościami } \\
\text { fizycznymi jak i } \\
\text { cechami natury } \\
\text { osobowościowej) }\end{array}$ & $\begin{array}{l}\text { Męczliwość, brak koncentracji lub jej } \\
\text { szybka utrata, trudności w skupieniu } \\
\text { się na jednej czynności, problemy z } \\
\text { motywacją na lekcji (szybka utrata } \\
\text { motywacji, niski jej próg). }\end{array}$ & $\begin{array}{l}\text { Motywowanie ucznia do pracy, } \\
\text { wprowadzanie ćwiczeń } \\
\text { relaksacyjnych, odpowiednie } \\
\text { dobieranie par i grup (uczeń z } \\
\text { dysleksja powinien być } \\
\text { przydzielony do grupy lub } \\
\text { pary, w której koledzy potrafią }\end{array}$ \\
\hline
\end{tabular}


Dysleksja rozwojowa w kontekście edukacji obcojęzycznej ...

\begin{tabular}{|l|l|l|}
\hline & $\begin{array}{l}\text { narzucić tempo i podział pracy } \\
\text { nie naruszając jednocześnie } \\
\text { autonomii ucznia). }\end{array}$ \\
\hline
\end{tabular}

Tabela 1: Przykładowe sposoby kompensacji objawów dysleksji rozwojowej na lekcji języka obcego.

\section{Zakończenie}

Współczesna wiedza na temat zjawiska dysleksji jest bogata. Świadomość problemu jest także coraz większa. Niestety program nauczania nadal nie jest dostosowany do wymagań edukacyjnych ucznia dyslektycznego. Patrząc z perspektywy ucznia polskiego można powiedzieć, że problem dysleksji nadal nie pozostał rozwiązany w szkołach, co wiąże się z potrzebą zmian w tym kierunku, przede wszystkim potrzebą lepszej wiedzy i przygotowania nauczycieli i adeptów zawodu nauczyciela języka obcego do radzenia sobie z trudnościami uczniów w nauce, kooperacji specjalistów z różnych dziedzin, włączenia szkoły i władz oświatowych w działania na rzecz tworzenia środowiska przyjaznego dysleksji.

\section{BIBLIOGRAFIA}

Alegria, J., Pignot, F. i Morais, J. 1982. „Phonetic analysis of speech and memory codes in beginning readers". Memory and Cognition 10. 451-6.

Bentin, S., Hammer, R. i Cahan, S. „The effects of aging and first grade schooling on the development of phonological awareness". Psychological Science 2. 271-4.

Bogdanowicz, M. 2004. „Niespecyficzne i specyficzne trudności w uczeniu się języków obcych", w: Bogdanowicz, M. i Smoleń, M. (red.). Dysleksja w kontekście nauczania jezyków obcych. Gdańsk: Harmonia. 78-98.

Bogdanowicz, M., Adryjanek, A. 2005. Uczeń z dysleksja w szkole. Gdynia: Operon.

Bradley, L., Bryant, P. E. 1983. „Categorising sounds and learning to read - a casual connection". Nature 301. 419-521.

Connelly, V. 1993. „The influence of instructional technique on the reading strategy of beginning readers". Poster presented at the VIth European Conference on Developmental Psychology, Bonn, Germany.

Crombie, M. 1997b. Specific Learning Difficulties: Dyslexia - A Teacher's Guide. Belford: Ann Arbor Publishers.

DiFino, S., Johnson, B. i Lombardino. L. 2008. „College students with dyslexia in fulfilling foreign language requirements: A case study". Contemporary issues in communication science and disorders 35. 54-64.

Downey, D., Snyder, L. i Hill, B. 2000. „College students with dyslexia: Persistent linguistic deficits and foreign language learning". Dyslexia 6. 101-111.

Frith, U. 1999. „Paradoxes in the definition of dyslexia”. Dyslexia 5. 192-214. 
Frost, R., Ziegler J. 2007. „Speech and spelling interaction: the interdependence of visual and auditory word recognition", w: Gaskell, G. (red.). The Oxford Handbook of Psycholinguistics. Oxford - New York: Oxford University Press. 107-115.

Ganschow, L., Schneider, E. i Evers, T. 2000. „Difficulties of English as a foreign language for students with language-learning disabilities", w: Peer, L. i Reid, G. (red.) Multilingualism, Literacy and Dyslexia. London: David Fulton Publishers. 182-192.

Geva, E. 2000. „Issues in the assessment of reading disabilities in children who are working in their second language - beliefs and research evidence". Dyslexia 6 (1). 13-28.

Gilinghman, A., Stillman, B. 1960. Remedial training for children with specific disability in reading, writing and penmanship. Cambridge, MA: Educators Publishing.

Glushko, R. J. 1979. „The organisation and activation of orthographic knowledge in reading aloud". Journal of Experimental Psychology: Human Perception and Performance 5 (4). 674-91.

Goswami, U. 1997. „Learning to read in different orthographies: phonological awareness, orthographic represenations and dyslexia", w: Hulme, C. i Snowling, M. (red.). Dyslexia: Biology, Cognition and Intervention. London: Whurr Publishers. 131-152.

Goulandris, N. 2003. Dyslexia in Different Languages: Cross Linguistic Comparisons. London: Whurr Publishers.

Hatcher, J., Snowling, M. 2008. „Hipoteza reprezentacji fonologicznych jako sposób rozumienia dysleksji: od teorii do praktyki”, w: Reid, G. i Wearmouth J. (red.). Dysleksja. teoria i praktyka. Gdańsk: Gdańskie Wydawnictwo Psychologiczne.

Hatcher, P., Hulme, C. i Ellis, A. W. 1994. „Ameliorating early reading failure by integrating the teaching of reading and phonological skills: the phonological linkage hypothesis". Child Development 65. 41-57.

Høien, T., Lundberg, I. 1988. „Stages of word recognition in early reading development". Scandinavian Journal of Educational Research, 32. 163-182.

Jaworska-Biskup, K. 2010. „Specjalne potrzeby edukacyjne dzieci i ich realizacja w szkole", w: Guz, S. i Zwierzchowska, I. (red.). O pomysilny start szkolny driecka. Warszawa: Wydawnictwo Comandor. 295-303.

Katz, L. i Feldman. L. B. 1981. „Linguistic coding in word recognition”, w: Lesgold, A. M. i Perfetti, C. A. (red.) Interactive Processes in Reading. Erlbaum: Hillsdale, NJ. 85-105.

Krasowicz-Kupis, G. 2006. Dysleksja rozwojowa - perspektywa psychologiczna. Gdańsk: Harmonia.

Krasowicz-Kupis, G. 2008. Psychologia dysleksji. Warszawa: Wydawnictwo Naukowe PWN.

Lewis, M., Ellis, S. 2009. Phonics. Practice, Research and Policy. London: Sage. 
Liberman, I. Y., Liberman, A. M., Mattingly, I. G. i Shankweiler D. 1980. „Orthography and the beginning reader", w: Kavanagh, J. F. i Venezky, R. L. (red.). Orthography, Reading and Dyslexia. Pro-Ed Austin, TX. 137-53.

Lundberg, I., Olofsson, A. i Wall, S. 1980. „Reading and spelling skills in the first school years predicted from phonemic awareness skills in kindergarten". Scandinavian Journal of Psychology 21. 159-173.

Nijakowska, J. 2004. „Usprawnianie umiejętności odczytywania i zapisywania wyrazów w języku angielskim młodzieży z dysleksją rozwojową", w: Bogdanowicz, M. i Smoleń, M. (red.). Dysleksja w kontekśsie nauczania jezyków obcych. Gdańsk: Harmonia. 144-157.

Nijakowska, J. 2007. Understanding developmental dyslexia. Łódź: Łódź University Press. Petrus, P i Bogdanowicz, M. 2004. „Sprawność fonologiczna dzieci w kontekście nauki języka angielskiego", w: Bogdanowicz, M. i Smoleń, M. (red.). Dysleksja w kontekśsie nauczania jezyków obych. Gdańsk: Harmonia. 54-63.

Reid, G. 2007. Dyslexia. London: Continuum.

Schneider, E., Crombie, M. 2003. Dyslexia and foreign language learning. London: David Fulton Publishers.

Siegel, L., Smythe, I. 2004. „Dyslexia and English as an additional language: towards a greater understanding", w: Reid, G. i Fawcett, A. (red.). Dyslexia in context. London: Whurr Publishers.

Snowling, M. 2000. Dyslexia. Oxford: Blackwell Publishing.

Sparks, R., Ganschow, L. i Pohlman, J. 1989. „Linguistic coding deficits in foreign language learners". Annals of Dyslexia, 39. 179-195.

Sparks, R., Artzer, M., Patton, J., Ganschow, L., Miller, K., Hordubay, D. i Walsh, G. 1998c. „Benefits of multisenosory structured instruction for at risk foreign language learners: a comparison study of high school Spanish students". Annals of Dyslexia 48. 239-270.

Stanovich, K. E. 1988. „Explaining the differences between the dyslexic and the garden variety poor reader: the phonological core variable difference model". Journal of Learning Disabilities 21 (10). 590-612.

Stuart, M., Coltheart, M. 1988. „Does reading develop in a sequence of stages?” Cognition 30. 139-181.

Szczerbiński, M. 2003. „Dyslexia in Polish”, w: Goulandris, N. (red.). Dyslexia in different languages: Cross-linguistic comparisons. London: Whurr Publishers. 68-91.

Szczerbiński, M. 2007. „Dysleksja rozwojowa. Próba definicji”, w: KostkaSzymańska, M., i Krasowicz-Kupis, G. (red.). Dysleksja-problem znany czy nieznany? Lublin: Wydawnictwo UMCS. 47-70.

Topping, K. 2008. „Myślenie w parach. Ustrukturyzowana interakcja z rówieśnikami, rodzicami i wolontariuszami”, w: Reid, G. i Wearmouth, J. (red.). Dysleksja. Teoria i Praktykea. Gdańsk: Operon. 403-425.

Turner, E., Pughe, J. 2003. Dyslexia and English. London: David Fulton Publishers. 
Wimmer, H., Mayringer, H. i Raberger, T. 1999. „Reading and balancing: Evidence against the automatization deficit explanation of developmental dyslexia". Journal of Learning Disabilities, 32. 473-478. 